\title{
Knowledge Sharing between Marketing and Accounting from a Coopetitive Perspective: Empirical Evidence from Vietnam
}

\author{
NGUYEN PHONG NGUYEN \\ University of Economics HCMC - nguyenphongnguyen@ueh.edu.vn \\ DOAN NGOC QUE \\ University of Economics HCMC - dnque20@ gmail.com \\ NGUYEN DUNG HAI \\ University of Economics HCMC - dunghai@ ueh.edu.vn
}

\section{ARTICLE INFO ABSTRACT}

Article history:

Received:

Jun. 13, 2016

Received in revised form:

Sep. 5, 2016

Accepted:

Sep. 23, 2016

Keywords:

Coopetition, knowledge sharing between marketing and accounting, organizational innovativeness.
This study examines cross-functional knowledge sharing at the interface between marketing and accounting departments within business organizations. It develops a coopetition model to examine the effects of contingent variables including cross-functional competition and organizational innovativeness on the coordination-sharingperformance $(\mathrm{C}-\mathrm{S}-\mathrm{P})$ link. The results obtained from a survey of 178 large firms in Vietnam demonstrate that except formalization all coordination mechanisms including lateral relations, informal networking, and shared visions have positive influences on the knowledge sharing at the interface between marketing and accounting departments. Moreover, competition between these moderates the effects of both lateral relations and informal networking on the extent of knowledge sharing between the marketing and accounting departments (MAKS). Finally, this study finds that organizational innovativeness partially mediates the MAKS-performance link, emphasizing the role of innovation in transforming knowledge to performance. 


\section{Introduction}

The marketing literature has emphasized the performance implication of knowledge sharing between marketing and other departments in business organizations, which creates various competitive benefits including market learning (Luo et al., 2006), innovation (Tsai, 2001), and new product success (Ernst et al., 2010). The accounting literature also supports this view, highlighting the need of the cooperative interactions between marketing and accounting departments in terms of knowledge sharing. For example, the marketing department provides the accounting department with market information via customer ordering systems, account receivable collections, and budgets for marketing campaigns to develop financial and operational plans. The marketing department, in turn, receives financial knowledge from the accounting department, including product and service costing to make decisions for each business segment (Nguyen, 2014). Knowledge regarding budgeting, customer profitability, and cost variance analysis generated from the accounting department allows the marketing department to make various decisions concerning pricing, product-mix, and customer relationship management (Ratnatunga et al., 1988).

Our literature review found a coordination-sharing-performance (C-S-P) hypothesis, which posits that cross-functional coordination determines cross-functional knowledge sharing. The cross-functional coordination is the integration between different parts of an organization to achieve a collective set of tasks and goals, being a crucial antecedent of knowledge sharing (Tsai, 2002; Willem et al., 2006). Obviously, both formal coordination mechanisms (e.g., formalization and lateral relations) and informal coordination mechanisms (e.g., informal networking and shared vision) enable companies to develop communication channels, promote inter-functional cooperation, enhance social interactions between departments, and function as important devices to integrate different pools of knowledge through the organizational network structure (Gupta \& Govindarajan, 2000).

Although previous studies have significant contributions to the cross-functional knowledge sharing literature (Luo et al., 2006), several research gaps remain. First, empirical studies comparing the relative effects of different coordination mechanisms (i.e. formalization, lateral relations, informal networking, and shared vision) on MAKS are scant. The relative importance of each coordination mechanisms in enhancing knowledge sharing between departments (i.e. marketing and accounting) is still 
unknown. Under resource constraints managers need to use appropriate mechanisms to maximize MAKS. Second, extant literature on the $\mathrm{C}-\mathrm{S}-\mathrm{P}$ link largely ignores the moderating role of cross-functional competition. The review of both marketing and accounting literature detected a lack of empirical evidence about the performance implications of knowledge sharing between the marketing department and the accounting department in the context of cross-functional competition. The question remains unanswered as to whether cross-functional competition promotes or impedes the coordination-knowledge sharing relationship. Third, cross-functional knowledge is a firm's strategic resource, and realizing its potential value "requires alignment with other important organizational elements" such as organizational innovativeness (Ketchen et al., 2007). Finally, most cross-functional knowledge sharing studies have been conducted in Western developed countries; thus, the C-S-P link in transitional economies and collectivist cultures need to be tested.

To bridge these above gaps we draw on the social capital theory (Adler \& Kwon, 2002; Inkpen \& Tsang, 2005) and social embeddedness framework (Granovetter, 1985) to develop a coopetition model by adding two contingent factors to the $\mathrm{C}-\mathrm{S}-\mathrm{P}$ link. These factors are: (i) competition between marketing and accounting; and (ii) organizational innovativeness. Next, we validate the coopetition model against a sample of 178 large business organizations in Vietnam, a transitional economy. This paper is presented as follows. We initially review the previous studies concerning the $\mathrm{C}-\mathrm{S}-\mathrm{P}$ relationships, and then based on the contingency theory we add the two contingent factors to the $\mathrm{C}-\mathrm{S}-\mathrm{P}$ logic. The research design and analysis will be next presented in addition to the research results and discussion.

\section{Theoretical background, research model, and hypotheses}

Building on within-organization cooperation and competition perspectives (Brandenburger \& Nalebuff, 1995), we argue that cooperation and competition between marketing and other departments coexist and help develop a coopetition framework. Competition arises through diverging interests between parties, creating a win-lose scenario or a zero-sum game structure. The opposite perspective, cooperation, emphasizes cooperative interdependencies with fully converging interests (Walley, 2007). This perspective suggests that collaboration is a critical factor for strategic success that brings growth for all parties under a positive-sum game structure (Hill, 
1990). Both perspectives have attracted a major criticism for their bias toward different poles of a relationship when, in fact, they equally determine important interdependencies within an organization (Bengtsson \& Kock, 2000). The coopetition perspective, on the other hand, indicates that the coexistence of competition and cooperation determines the organization's interdependencies through a variable-positive-sum game (Dagnino, 2009).

Regarding the relationships among departments in an organization, there is a tradeoff between cooperation and competition, which are at the opposite ends of a continuum. Competition is generally defined as the conflicting and rivalling relationship among parties (Bengtsson \& Kock, 2000). Departments may experience problems coordinating work activities because they have disagreements about the priorities of others, hinder others' performance, and do not cooperate with one another (Maltz \& Kohli, 1996). In the presence of cross-functional rivalry, departments are less likely to share knowledge, or they will avoid using knowledge shared from the others because acting on the knowledge shared "would be tantamount to being influenced or controlled" by the sharers (Maltz \& Kohli, 1996). Luo et al. (2006) argued that the interaction between functional departments may be a "double-edged sword," involving both cooperation and competition. Indeed, departments do not only cooperate to achieve the ultimate organizational goals (Narver \& Slater, 1990), but they also compete to pursue their own strategic priorities or to defend against loss of status or power (Houston et al., 2001). Take for example the cross-functional conflicts between marketing and accounting. The accounting department views the marketing department as an area that incurs too much expenses while it is difficult to measure and evaluate the relationships between marketing expenditures or budgets and the future effectiveness of these expenditures or budgets, which, therefore, are likely to be cut by the accounting department. Meanwhile, the marketing department blames the accounting department for its too conservative decisions that lead to an increasing market to book ratio (Sidhu \& Roberts, 2008). While departments are determining their roles, identities, and power bases through separations of tasks, they are strongly motivated to defend against loss of status or power (Hutt et al., 1995).

\subsection{Social capital theory}

Social capital theory relates to "goodwill available to individuals or groups" generated by social relationships (Adler \& Kwon, 2002) or simply an organizational 
network of relationships (Inkpen \& Tsang, 2005), containing three dimensions: structural, cognitive, and relational (Nahapiet \& Ghoshal, 1998). In this study we propose four coordination mechanisms, including formalization, lateral relations, informal networking, and shared vision, which well reflect all the three dimensions of social capital. Formalization is the extent to which policies, rules, task descriptions, and procedures are written down in manuals and established as standard routines (relational). Lateral relations refer to the horizontal links among organizational units that reflect the connections between employees from different units at the same hierarchical level (structural). Informal networking involves the informal relationships between employees from different parts of an organization (relational), whereas shared vision is defined as a shared value culture that enables individuals to communicate "the way of doing things, decision making styles, and objectives and values of the company" (cognitive).

Authors in favor of the social capital perspective contributed to formalization research by raising the relational aspect of social capital (Inkpen \& Tsang, 2005; Nahapiet \& Ghoshal, 1998) as a determinant of social relations among different departments, which is beneficial for knowledge sharing. Formalization improves cooperation and collaboration among workers because it can shape the scope of crossfunctional interactions and facilitate the transfer of explicit knowledge by means of rules (Cordon-Pozo et al., 2006).

Lateral relations among departments exhibit the network ties in an organization, which belong to the structural dimension of social capital (Inkpen \& Tsang, 2005). The development of these relations depends on organizational practices such as liaison roles, temporary and permanent teams (Gupta \& Govindarajan, 2000; Persson, 2006; Willem \& Buelens, 2007; Willem et al., 2006), and joint work in task forces (Ghoshal et al., 1994). Jansen et al. (2005) found that cross-functional integrators, such as liaison staff and task forces, stimulate the integration of existing and newly acquired knowledge and enhance organizational units' capacity to develop novel linkages and associations.

From the social capital perspective, informal networking is a facilitator of knowledge sharing because of its role in the creation of common knowledge (Tsai, 2002; Willem et al., 2006) and connections between departments (Tagliaventi et al., 2010). Further informal networks such as personal networks enhance the intensity and effectiveness of 
knowledge sharing (Willem \& Buelens, 2007) by developing cooperative and reciprocal norms (Luo \& Hassan, 2009).

Finally, shared vision refers to a culture of shared values that enables a consistent "way of doing things, decision making styles, and objectives and values of the company" (Martinez \& Jarillo, 1989). Shared vision creates mutual trust in an organizational network (Willem et al., 2006) and displays the cognitive dimension of social capital (Inkpen \& Tsang, 2005; Nahapiet \& Ghoshal, 1998) as it brings workers together and fosters a commitment to mutual goals (e.g., Dawes \& Massey, 2005; Maltz \& Kohli, 1996; Maltz et al., 2001). It is a key determinant of cross-functional knowledge sharing due to its significant role in promoting cooperation and willingness to share information and ideas in order to achieve mutual goals (Fey \& Furu, 2008), such as sales, market share, return on investment, rate of new product introduction, and customer satisfaction (Baker \& Sinkula, 1999). Therefore, we propose that:

H1: Formalization has a positive effect on MAKS.

H2: Lateral relations have a positive effect on MAKS.

H3: Informal networking has a positive effect on MAKS.

H4: Shared vision has a positive effect on MAKS.

\subsection{Social embeddedness framework}

Social embeddedness refers to how individuals are structurally embedded in a network of social relations (Granovetter, 1985). Social embeddedness theory proposes that the subsequent behaviors of individuals are affected by the social structure of their relations (Granovetter, 1985; Luo et al., 2006). There are two types of social relations: strong ties and weak ties. Strong ties are characterized by a high level of cooperation and frequent interaction regulated by reciprocity, trust, or group norms (Granovetter, 1973; Rindfleisch \& Moorman, 2001). Strong ties are effective for transferring tacit knowledge (Hansen, 1999; Reagans \& McEvily, 2003; Uzzi, 1997) because through a high level of trust and cooperation they allow people to interact closely and frequently to share tacit knowledge, which requires more time and effort than sharing explicit knowledge. In contrast, weak ties are characterized by competition, infrequent interaction, lack of trust, and limited affect (Dahlstrom \& Ingram, 2003; Uzzi, 1999). They can connect diverse groups of people who have diverse pools of knowledge yet do not frequently interact (Burt, 1995), and provide them with new and non-redundant 
knowledge. Thus, weak ties are needed to access new and diverse knowledge (Hansen, 1999); they are more effective in searching for and transferring explicit knowledge (Reagans \& McEvily, 2003). Weak ties can foster the learning process by motivating competitors to search for each other's knowledge (Quintana-García \& BenavidesVelasco, 2004; Tsai, 2002). A combination of strong and weak ties adds greater value to a business than strong or weak ties alone (Luo et al., 2006).

The interactions between marketing and accounting departments involve both competition and cooperation aspects. According to the social embeddedness framework, the cooperation aspect implies strong ties between these two departments and can be established by coordination mechanisms (e.g., formalization, lateral relation, informal networking, and shared vision). These mechanisms can promote sharing tacit knowledge across functional boundaries, in line with the above discussion regarding H4. The competition aspect, which implies weak ties between the marketing and accounting departments, creates more motivation for these departments to learn from one another and promotes explicit knowledge transfer between them. This implies that the combination between competition (weak ties) and cooperation (strong ties) may encourage knowledge sharing between these departments (Tsai, 2002). Hence, we argue that the competition between marketing and accounting departments (weak ties) strengthens the effect of coordination mechanisms (strong ties) on cross-functional knowledge sharing. In other words, the impact of coordination mechanisms on crossfunctional knowledge sharing between marketing and accounting departments is stronger in the presence of competition between these departments. Drawing upon the social embeddedness framework, we thus propose the following hypothesis:

H5: Competition between marketing and accounting departments moderates the positive relationships of: (i) formalization, (ii) lateral relations, (iii) informal networking, and (iv) shared vision, with MAKS.

Knowledge is often critical to the innovation process. The grandness of knowledge sharing for enhancing organizational innovativeness has been emphasized widely in relevant literature (Lin, 2007; Tagliaventi et al., 2010). Since knowledge is embedded in individuals from different departments, it needs to be shared to generate new ideas and ways of doing things. If an organization can disseminate knowledge across its functional boundaries, it can integrate diverse ideas and perspectives from different departments, which should result in innovative ideas (Brettel et al., 2011). In addition, by facilitating 
knowledge sharing organizations can reduce interdepartmental conflicts (Griffin \& Hauser, 1996), and thus direct departments' behaviors toward learning from each other. The spread of learning among departments, in turn, increases the opportunities to create new knowledge and diffuse novel ideas. Acquiring new knowledge increases the likelihood of innovation because departments are exposed to new knowledge that interacts with the knowledge they already held. Therefore, we argue that knowledge sharing between marketing and accounting departments has a positive impact on organizational innovativeness.

In a rapid changing environment it is crucial for business organizations to engage in innovative activities to develop new products and exploit market opportunities. These activities enhance sales and market share since customers tend to buy innovative and distinct products that meet their needs and bring superior value to them (Sandvik \& Sandvik, 2003). In general, organizations with a high degree of innovativeness can respond actively to the changes in the business environment and develop new capabilities that bring about a competitive edge and a superior performance (Hult et al., 2004). The marketing literature suggests that an organization's innovativeness has a positive effect on performance (Calantone et al., 2002). A high level of innovativeness is associated with more timely and creative introduction of new products and services that provide superior value to customers (Olavarrieta \& Friedmann, 2008). In addition, organizations must be innovative to gain a competitive advantage for survival and to stay ahead of their rivals ( $\mathrm{Li} \&$ Calantone, 1998). Therefore, organizational innovativeness can have positive influence on firm performance.

In light of the above reasoning we posit that knowledge sharing between marketing and accounting departments promotes organizational innovativeness, which, in turn, enhances firm performance. This reflects the mediating role of organizational innovativeness on the nexus between MAKS and firm performance. Accordingly:

H6: Organizational innovativeness mediates the relationship between MAKS and firm performance.

Figure 1 illustrates the proposed model for developing the above hypotheses. 


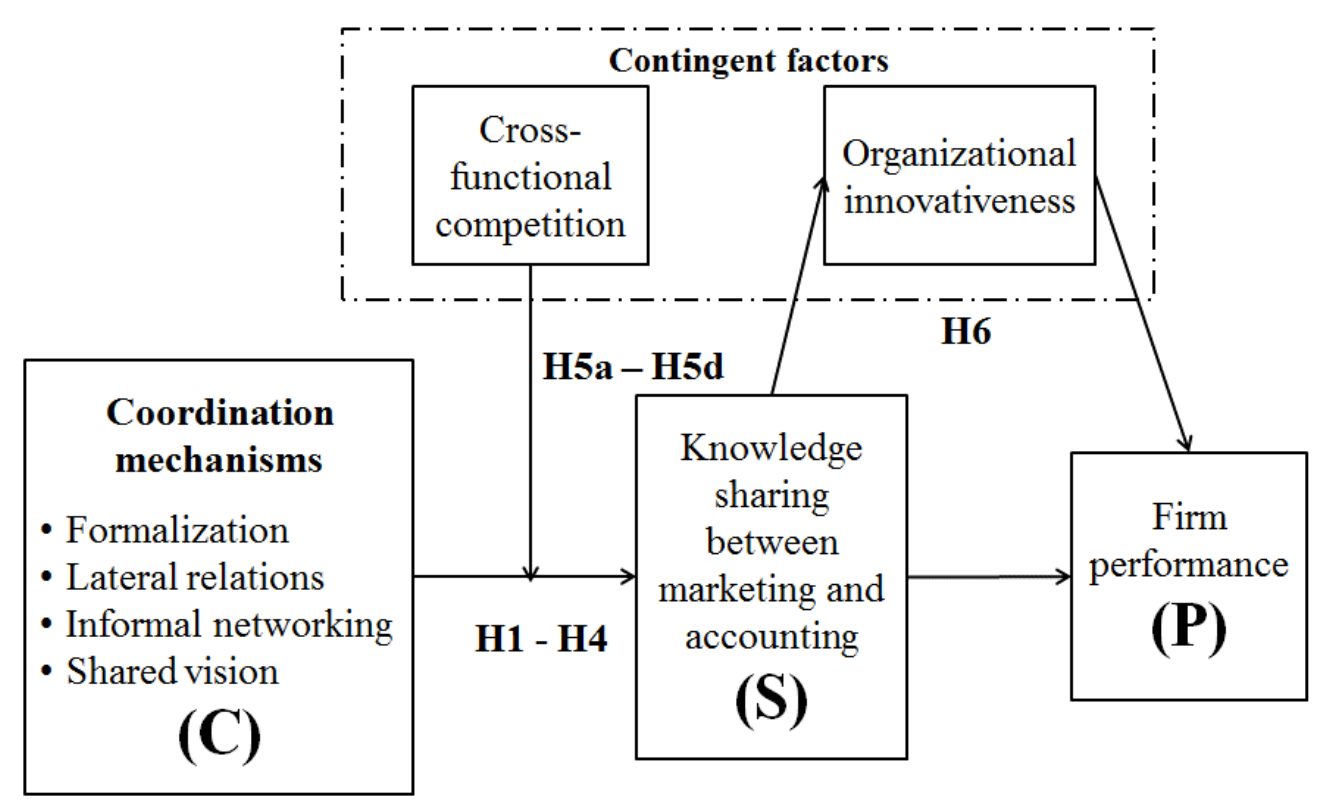

Figure 1. The proposed model

\section{Research method}

\subsection{Sampling and sampling frame}

This study was conducted in Vietnam, an emerging economy with a dataset of 178 large business firms. According to Degree 56 ND-CP of the Vietnamese government, the criteria for categorizing a firm as being large are as follows. For the manufacturing industry, firms need to have total capital of more than VND100 billion, or more than 300 full-time equivalent employees. For service and trading industries, firms need to have total capital of more than VND50 billion, or more than 100 full-time equivalent employees (Vietnamese Government, 2009). To overcome budget and time constraints we have adopted the convenience-sampling approach to collect our survey data. This approach involves selecting firms that are accessible and have potential informants that are willing to participate in the survey. We, therefore, have selected CEOs and members of the board of management and other mid-level managers from different marketing and accounting departments of large-sized firms.

The source of emails was constructed from the LinkedIn professional network, containing more than 3,000 emails of the potential informants. From February to April 2016 emails were sent to the potential informants via SurveyMonkey, an online survey 
tool. After two months with two reminder emails with three-week intervals, 460 completed responses were collected.

By eliminating responses from small and medium firms, and invalid and careless responses with too short response duration (less than five minutes), we have obtained a final sample of 178 responses with the following industry structure: manufacturing (33.1\%), trading (23.6\%), and services firms (43.8\%). The sampled firms include those with total assets of more than VND200 billion (89.9\%) and those with full-time equivalent employees of more than 500 (76.4\%). Moreover, the final sample features mid-level managers (42.7\%) and top-manager respondents (57.3\%). Due to the presence of 23 firms with informants with tenure of less than two years in our sample, the positions of these informants should be thoroughly examined. We find that most of them are top managers, who should be knowledgeable about research issues regarding their companies and could represent their companies to answer the survey questions. The average tenure of the respondents of 6.7 years indicates that they have adequate experience to represent their firms to answer the survey.

Due to a low response rate of 5.9\% we have also conducted a non-response bias test following the procedure recommended by Armstrong and Overton (1977). The independent $\mathrm{t}$-tests reveal no statistically significant differences in all key measures among the first (earliest) and fourth (latest) quartiles of responses, signifying no response bias in this study.

\section{Table 1}

Demographic information

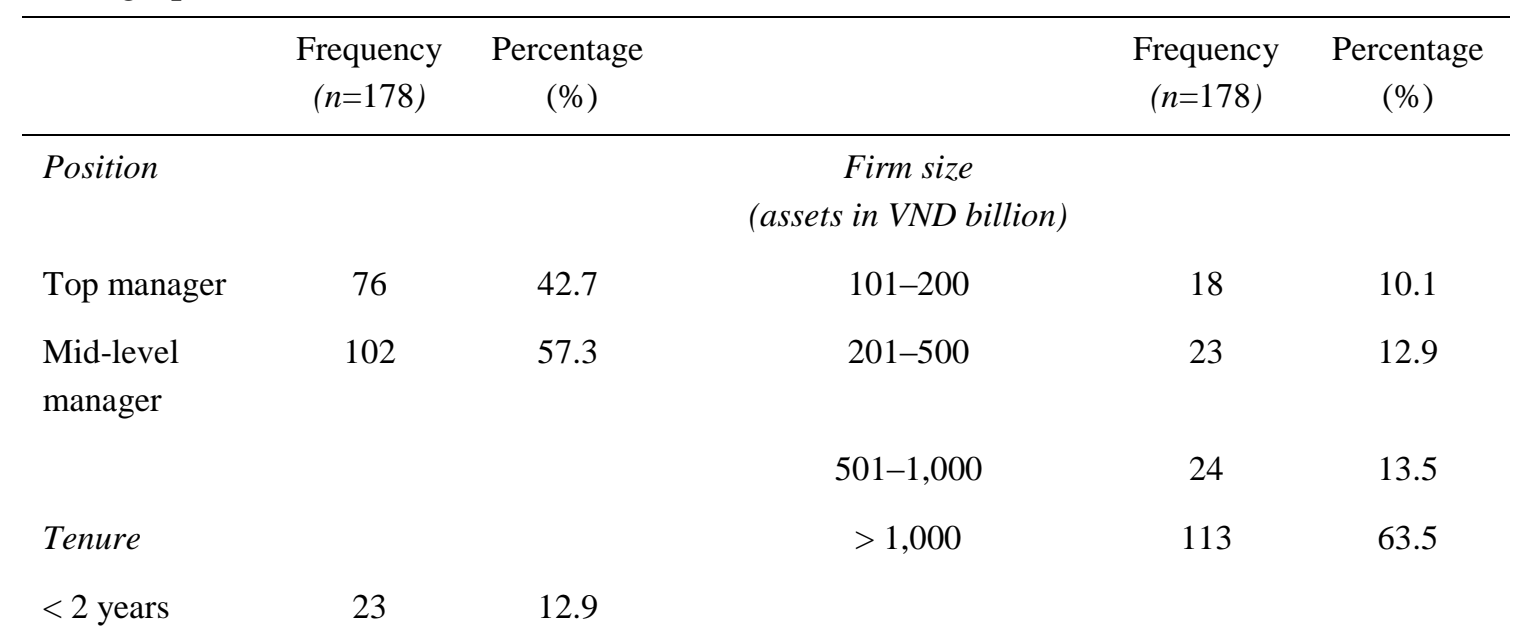




\begin{tabular}{|c|c|c|c|c|c|}
\hline & $\begin{array}{l}\text { Frequency } \\
\qquad(n=178)\end{array}$ & $\begin{array}{l}\text { Percentage } \\
(\%)\end{array}$ & & $\begin{array}{l}\text { Frequency } \\
(n=178)\end{array}$ & $\begin{array}{l}\text { Percentage } \\
\quad(\%)\end{array}$ \\
\hline $2-5$ years & 72 & 40.5 & $\begin{array}{c}\text { Firm size (full-time } \\
\text { employees) }\end{array}$ & & \\
\hline $6-10$ years & 48 & 27.0 & $201-500$ & 42 & 23.6 \\
\hline $11-20$ years & 25 & 14.0 & $501-1,000$ & 48 & 27.0 \\
\hline \multirow[t]{2}{*}{$>20$ years } & 10 & 5.6 & $1,001-5,000$ & 53 & 29.8 \\
\hline & & & $5,001-10,000$ & 16 & 9.0 \\
\hline Industry type & & & $>10,000$ & 19 & 10.7 \\
\hline Manufacturing & 58 & 32.6 & & & \\
\hline Trading & 41 & 23.0 & Ownership & & \\
\hline \multirow[t]{2}{*}{ Services } & 79 & 44.4 & $\begin{array}{c}100 \% \text { foreign-owned } \\
\text { enterprise }\end{array}$ & 53 & 29.8 \\
\hline & & & $\begin{array}{l}\text { State-owned enterprise } \\
(\geq 51 \% \text { states capital) }\end{array}$ & 18 & 10.1 \\
\hline Firm age & & & Private company & 57 & 32.0 \\
\hline$\leq 5$ years & 19 & 10.7 & $\begin{array}{l}\text { Joint venture with } \\
\text { international partner }\end{array}$ & 28 & 15.7 \\
\hline $6-10$ years & 32 & 18.0 & $\begin{array}{l}\text { Joint venture with local } \\
\text { partner }\end{array}$ & 7 & 3.9 \\
\hline $11-20$ years & 68 & 38.2 & Others & 15 & 8.4 \\
\hline $21-50$ years & 49 & 27.5 & & & \\
\hline$>50$ years & 10 & 5.6 & & & \\
\hline
\end{tabular}

\subsection{Measurement scales and reliability and validity tests}

We measure formalization, lateral relations, informal networking, shared vision, MAKS, and competition between marketing and accounting departments, using adopted and adapted scales from the literature (Calantone et al., 2002; Ghobadi \& D'Ambra, 2012; Luo et al., 2006; Willem \& Buelens, 2009). All of these constructs are evaluated by seven-point Likert scales anchoring from 1 (strongly disagree) to 7 (strongly agree). To test the proposed hypotheses we use power distance (measured by a five-point Likert 
scale) and firm ownership (measured by a dummy code: $0=$ without foreign capital, $1=$ with foreign capital) as two control variables with the scales adopted from Zhang and Begley (2011) and Luo et al. (2006). Table 2 shows the scale items of the main constructs in the proposed model.

Common method bias is also tested using the non-statistical and statistical remedies suggested by Podsakoff et al. (2003). We find that common method bias is not a serious problem in our dataset. In addition, the factor loadings of the main constructs in the model (from 0.52 to 0.96 ) exceed the cut-off value of 0.50 (see Table 2). The composite reliabilities of all main constructs range between 0.79 and 0.95 . The square roots of AVEs (from 0.75 to 0.89 ) exceed all corresponding correlation coefficients; hence, the convergent validity and discriminate validity of the measurement items are achieved.

\section{Table 2}

Scale items and latent variable evaluation

\begin{tabular}{ll}
\hline Variable & Loading \\
\hline
\end{tabular}

Formalization, $A V E=0.56$; Composite reliability $=0.79$ (adapted from Willem \&

Buelen, 2007, 2009)

Formal procedures determine how the marketing department and the accounting department work together with each other

In my company we have clear goals for our daily work performance

The information that is required to do tasks in the marketing department and accounting department is laid down in procedures, goals, and rules

Lateral relations, $A V E=0.67$; Composite reliability $=0.89$ (adapted from Willem \& Buelen, 2007, 2009)

Cross-functional teams composed of workers from the marketing department and the accounting department are set up to allow for cooperation and joint decision-making in my company

In my company task forces (project teams) are set up to facilitate collaboration between marketing and accounting departments

In my company information and experiences are often shared between the marketing department and the accounting department in meetings or during teamwork 
Variable

Loading

The person responsible for the cooperative activities is authorized to make all necessary agreements to facilitate cooperation between the marketing department and the accounting department

Informal networking, AVE $=0.63$; Composite reliability $=0.87$ (adapted from Willem \& Buelen, 2007, 2009)

In my company we coordinate the activities between the marketing department and the accounting department via personal contacts

In my company we confer directly with our personal contacts without consulting our supervisors

In my company we contact directly the colleagues who we know well in the marketing department or the accounting department when we need information

In my company cooperation between marketing and accounting departments is based on personal contacts

Competition between marketing and accounting, $A V E=0.65$; Composite reliability $=0.91$ (adapted from Luo et al., 2006)

Overall, marketing and accounting departments regularly compete for resources

When people from marketing and accounting departments discuss the distribution of resources among their departments, tensions frequently occur

Marketing and accounting departments tried to gain more strategic power during cross-functional projects

Marketing and accounting departments regularly compete with each other for more attention from top executives

Protecting one's departmental turf seemed to be a way of life of people from marketing and accounting departments

Shared vision, $A V E=0.76$; Composite reliability $=0.93$ (adapted from Calantone et al., 2002)

There is a commonality of purpose between the marketing department and the accounting department in my company

There is total agreement on our organizational vision across marketing and accounting departments in my company 


\begin{tabular}{|c|c|}
\hline Variable & Loading \\
\hline All workers are committed to the goals of my company & 0.92 \\
\hline Workers view themselves as partners in charting the direction of my company & 0.86 \\
\hline \multicolumn{2}{|l|}{ Knowledge sharing between marketing and accounting (MAKS), $A V E=0.65$; } \\
\hline \multicolumn{2}{|l|}{ Composite reliability $=0.89($ adopted from Calantone et al., 2002) } \\
\hline $\begin{array}{l}\text { In my company there is a good deal of organizational conversation that keeps alive } \\
\text { the lessons learned from history }\end{array}$ & 0.77 \\
\hline $\begin{array}{l}\text { In my company the marketing department and the accounting department always } \\
\text { analyze unsuccessful organizational endeavors and communicate the lessons learned } \\
\text { widely }\end{array}$ & 0.87 \\
\hline $\begin{array}{l}\text { In my company we have specific mechanisms for sharing lessons learned in } \\
\text { organizational activities between marketing and accounting departments }\end{array}$ & 0.83 \\
\hline $\begin{array}{l}\text { Top management repeatedly emphasizes the importance of knowledge sharing } \\
\text { between marketing and accounting departments }\end{array}$ & 0.81 \\
\hline \multicolumn{2}{|l|}{ Organizational innovativeness, $A V E=0.70 ;$ Composite reliability $=0.91$ (adopted from } \\
\hline \multicolumn{2}{|l|}{ Calantone et al., 2002) } \\
\hline My company frequently tries out new ideas & 0.89 \\
\hline My company seeks out new ways to do things & 0.89 \\
\hline My company is creative in its methods of operation & 0.89 \\
\hline My company is often the first to market with new products and services & 0.69 \\
\hline \multicolumn{2}{|l|}{$\begin{array}{l}\text { Organizational performance, } A V E=0.80 ; \text { Composite reliability }=0.95 \text { (adopted } \\
\text { Calantone et al., 2002) }\end{array}$} \\
\hline Return on investment (ROI) & 0.90 \\
\hline Return on sales (ROS) & 0.91 \\
\hline Sales growth & 0.83 \\
\hline Return on assets (ROA) & 0.91 \\
\hline Overall profitability & 0.89 \\
\hline
\end{tabular}




\section{Hypothesis testing and discussion}

To test H1-H5 we develop Model 1, including all independent variables except for organizational innovativeness (INNO). The results of Table 3 show that formalization $(\beta=-0.03 ; t=0.46)$ does not significantly influence MAKS, and thus H1 is not supported. However, lateral relations $(\beta=0.32 ; t=4.36)$, informal networking ( $\beta=0.23 ; t=2.29)$, and shared vision $(\beta=0.4 ; t=5.87)$ have positive and significant impacts on MAKS (supporting $\mathrm{H} 2, \mathrm{H} 3$, and $\mathrm{H} 4$ ). We also find that cross-functional competition (between marketing and accounting) does not moderate the links between formalization $(\beta=0.03 ; t=0.45)$ as well as shared vision $(\beta=-$ $0.01 ; t=0.18$ ) and MAKS. Hence, H5a and H5d are not supported. On the other hand, competition between marketing and accounting departments strengthens the positive relationship between lateral relations and MAKS ( $\beta=0.16 ; t=1.78)$, but weakens the positive relationship between informal networking and MAKS ( $\beta=-$ $0.33 ; t=2.02$ ), thus supporting $\mathrm{H} 5 \mathrm{~b}$ and $\mathrm{H} 5 \mathrm{c}$.

To test the mediating hypothesis $\mathrm{H} 6$ we follow the procedure suggested by Hair et al. (2016) and propose Model 2, which includes organizational innovativeness as the mediating variable on the relationship between MAKS and organizational performance. For Model 2 MAKS has a positive influence on organizational innovativeness (Model 2; $\beta=0.63 ; t=12.35$ ), which in turn has a positive effect on organizational performance (Model 2; $\beta=0.64 ; t=13.20$ ). By comparing Models 1 and 2, we find that the positive influence of MAKS on organizational performance in Model $1(\beta=0.57 ; t=12.89)$ is weaker than that in Model $2(\beta=0.16 ; t=2.94)$. However, the impact of MAKS on organizational performance in Model 2 (with organizational innovativeness employed as the mediating variable) is still significant. Therefore, organizational innovativeness does not fully (but it does partially) mediate the link between MAKS and organizational performance, thus supporting H6. 


\section{Table 3}

Structural equation parameter estimates ( $t$-value)

\begin{tabular}{|c|c|c|c|c|c|}
\hline & \multicolumn{5}{|c|}{ Dependent variable } \\
\hline & \multicolumn{2}{|c|}{ Model 1} & \multicolumn{3}{|c|}{ Model 2} \\
\hline & MAKS & PERF & MAKS & INNO & PERF \\
\hline \multicolumn{6}{|l|}{ Independent variables } \\
\hline FOR & $-0.03(0.46)$ & - & $\begin{array}{l}-0.03 \\
(0.45)\end{array}$ & - & - \\
\hline LATERAL & $0.32^{\mathrm{c}}(4.36)$ & - & $0.30^{c}(4.49)$ & - & - \\
\hline INFOR & $0.23^{\mathrm{b}}(2.29)$ & - & $\begin{array}{l}0.22^{\mathrm{b}} \\
(2.22)\end{array}$ & - & - \\
\hline SHARE & $0.40^{\mathrm{c}}(5.87)$ & - & $0.41^{c}(6.14)$ & - & - \\
\hline COMPE & $\begin{array}{l}-0.25^{\mathrm{c}} \\
(4.64)\end{array}$ & - & $\begin{array}{l}-0.25^{\mathrm{c}} \\
(4.45)\end{array}$ & - & - \\
\hline FOR $\times$ COMPE & $0.03(0.45)$ & - & $0.02(0.33)$ & - & - \\
\hline $\begin{array}{l}\text { LATERAL } \\
\text { COMPE }\end{array}$ & $0.16^{\mathrm{a}}(1.78)$ & - & $0.14^{\mathrm{a}}(1.81)$ & - & - \\
\hline INFOR $\times$ COMPE & $\begin{array}{l}-0.33^{\mathrm{b}} \\
(2.02)\end{array}$ & - & $\begin{array}{l}-0.33^{\mathrm{c}} \\
(2.05)\end{array}$ & - & - \\
\hline SHARE $\times$ COMPE & $-0.01(0.18)$ & - & $\begin{array}{l}-0.01 \\
(0.19)\end{array}$ & - & - \\
\hline MAKS & - & $\begin{array}{c}0.57^{\mathrm{c}} \\
(12.89)\end{array}$ & - & $\begin{array}{c}.63^{\mathrm{c}} \\
(12.35 \\
)\end{array}$ & $\begin{array}{l}0.16^{\mathrm{c}} \\
(2.94)\end{array}$ \\
\hline INNO & - & - & - & - & $\begin{array}{c}0.64^{\mathrm{c}} \\
(13.20 \\
)\end{array}$ \\
\hline
\end{tabular}

Control variables

Power distance $\quad-0.07(1.15) \quad-\quad-0.08$




\begin{tabular}{|c|c|c|c|c|c|}
\hline & \multicolumn{5}{|c|}{ Dependent variable } \\
\hline & \multicolumn{2}{|c|}{ Model 1} & \multicolumn{3}{|c|}{ Model 2} \\
\hline & MAKS & PERF & MAKS & INNO & PERF \\
\hline Ownership & - & $-0.02(0.36)$ & - & - & $\begin{array}{l}-0.01 \\
(0.15)\end{array}$ \\
\hline R-squared & 0.49 & 0.30 & 0.45 & 0.36 & 0.58 \\
\hline
\end{tabular}

Notes: a, b, and c denote a significance at $10 \%, 5 \%$, and $1 \%$, respectively (two-tailed $t$-test); FOR: formalization, LATERAL: lateral relations, INFOR: informal networking, SHARE: shared vision, COMPE: competition between marketing and accounting; MAKS: knowledge sharing between marketing and accounting, INNO: organizational innovativeness; PERF: organizational performance.

\subsection{Theoretical implications}

First, this study adds to the literature on intra-organizational coordination mechanism (e.g., Willem et al., 2006) and cross-functional knowledge sharing, focusing on the interface between marketing and accounting departments. Knowledge sharing between the marketing and other functional departments (including accounting) has received more concerns in organizational studies (Luo et al., 2006). Still, this research stream largely ignores both formal and informal coordination mechanisms in the presence of cross-functional competition. Building upon the social capital theory, this study fills the gap of this research stream by connecting different cross-functional coordination mechanisms, including both formal and informal ones, to MAKS in the context of crossfunctional competition. Social capital theory relates to goodwill available to individuals or groups and generated by social relationships or simply an organizational network of relationships (Inkpen \& Tsang, 2005). As discussed, it contains three dimensions: structural, cognitive and relational. This study has also suggested that lateral relations, informal networking, and shared vision are several major knowledge sharing determinants. These mechanisms represent well all of the three aforementioned dimensions of social capital, which have been proposed as the conditions required to facilitate knowledge sharing in an intra-organizational network. Hence, this study, we assume, provides empirical evidence to support social capital theory in explaining the role of coordination in promoting MAKS.

Second, this study extends the growing body of research on coopetition by examining the moderating role of competition in using coordination mechanisms to enhance knowledge sharing between the marketing and the accounting functions in an 
organization. Although the performance benefits of intra-organizational coopetition are increasing through studies that have investigated these benefits in a conceptual way (e.g., Padula \& Dagnino, 2007) and even though studies of coopetition and organizational performance exist, such empirical verification is limited (Walley, 2007). This study bridges this gap with the insights into the two conflicting processes of competition and coordination between the marketing and accounting departments in an organization that can have performance implications.

Finally, this study inspects the interrelationships among MAKS, coordination, and competition within organizations operating in a developing country, which is largely overlooked in the extant literature. Moreover, the study has shown that although crossfunctional competition has a positive moderating effect on the link between lateral relations and MAKS, it negatively moderates the positive association between informal networking and MAKS. These moderating effects are contradicting, which supports the notion that cross-functional competition may be a "double-edged sword" in the context of organizations in a transitional economy.

\subsection{Managerial implications}

First, the study provides guidance on MAKS for large business organizations to improve organizational performance. Second, the results suggest that large business organizations need to manage cross-functional coordination to enhance knowledge sharing between marketing and accounting departments. Attention should be paid especially to three cross-functional coordination mechanisms, namely lateral relations, informal networking, and shared vision, which significantly determine MAKS. Last, managers should recognize that competition is not always unfavorable. They should be aware that this benefit of cross-functional competition might be outweighed by other potential problems, for example, a reduction in the effect of informal networking on MAKS due to cross-functional competition. This carries an implication for management about how to control cross-functional competition effectively to promote MAKS, which is intended for better performance outcomes. 


\section{References}

Adler, P. S., \& Kwon, S. W. (2002). Social capital: Prospects for a new concept. Academy of Management Review, 27(1), 17-40.

Armstrong, J. S., \& Overton, T. S. (1977). Estimating nonresponse bias in mail surveys. Journal of Marketing Research, 14(3), 396-402.

Baker, W., \& Sinkula, J. (1999). The synergistic effect of market orientation and learning orientation on organizational performance. Journal of the Academy of Marketing Science, 27(4), 411-427.

Bengtsson, M., \& Kock, S. (2000). "Cooperation" in business networks - To cooperate and compete simultaneously. Industrial Marketing Management, 29(5), 411-426.

Brettel, M., Heinemann, F., Engelen, A., \& Neubauer, S. (2011). Cross-functional integration of $\mathrm{R} \& \mathrm{D}$, marketing, and manufacturing in radical and incremental product innovations and its effects on project effectiveness and efficiency. Journal of Product Innovation Management, 28(2), 251269.

Burt, R. S. (1995). Structural holes: The social structure of competition. Cambridge, MA: Harvard University Press.

Calantone, R. J., Cavusgil, S. T., \& Zhao, Y. (2002). Learning orientation, firm innovation capability, and firm performance. Industrial Marketing Management, 31(6), 515-524.

Cordon-Pozo, E., Garcia-Morales, V. J., \& Aragon-Correa, J. A. (2006). Inter-departmental collaboration and new product development success: A study on the collaboration between marketing and R\&D in Spanish high-technology firms. International Journal of Technology Management, 35(1-4), 52-79.

Dagnino, G. B. (2009). Coopetition strategy: A new kind of interfirm dynamics for value creation. In G. B. Dagnino \& E. Rocco (Eds.), Coopetition strategy: Theory, experiments and cases (pp. 2543). NY: Routledge.

Dawes, P. L., \& Massey, G. R. (2005). Antecedents of conflict in marketing's cross-functional relationship with sales. European Journal of Marketing, 39(11/12), 1327-1344.

Ernst, H., Hoyer, W. D., \& Rübsaamen, C. (2010). Sales, marketing, and research-and-development cooperation across new product development stages: Implications for success. Journal of Marketing, 74(5), 80-92.

Fey, C. F., \& Furu, P. (2008). Top management incentive compensation and knowledge sharing in multinational corporations. Strategic Management Journal, 29(12), 1301-1323.

Ghobadi, S., \& D'Ambra, J. (2012). Knowledge sharing in cross-functional teams: A coopetitive model. Journal of Knowledge Management, 16(2), 285-301.

Ghoshal, S., Korine, H., \& Szulanski, G. (1994). Interunit communication in multinational corporations. Management Science, 40(1), 96-110. 
Granovetter, M. S. (1973). The strength of weak ties. American Journal of Sociology, 78(6), 13601380.

Granovetter, M. S. (1985). Economic action and social structure: The problem of embeddedness. American Journal of Sociology, 91(3), 481-510.

Griffin, A., \& Hauser, J. R. (1996). Integrating R\&D and marketing: A review and analysis of the literature. Journal of Product Innovation Management, 13(3), 191-215.

Gupta, A. K., \& Govindarajan, V. (2000). Knowledge flows within multinational corporations. Strategic Management Journal, 21(4), 473-496.

Hair, J. F., Jr., Hult, G. T. M., Ringle, C., \& Sarstedt, M. (2016). A primer on partial least squares structural equation modeling (PLS-SEM). CA: Sage Publications.

Hansen, M. T. (1999). The search-transfer problem: The role of weak ties in sharing knowledge across organization subunits. Administrative Science Quarterly, 44(1), 82-111.

Hill, C. W. L. (1990). Cooperation, opportunism, and the invisible hand: Implications for transaction cost theory. Academy of Management Review, 15(3), 500-513.

Houston, M. B., Walker, B. A., Hutt, M. D., \& Reingen, P. H. (2001). Cross-unit competition for a market charter: The enduring influence of structure. Journal of Marketing, 65(2), 19-34.

Hult, G. T. M., Hurley, R. F., \& Knight, G. A. (2004). Innovativeness: Its antecedents and impact on business performance. Industrial Marketing Management, 33(5), 429-438.

Hutt, M. D., Walker, B. A., \& Frankwick, G. L. (1995). Hurdle the cross-functional barriers to strategic change. Sloan Management Review, 36(3), 22-30.

Inkpen, A. C., \& Tsang, E. W. K. (2005). Social capital, networks, and knowledge transfer. Academy of Management Review, 30(1), 146-165.

Jansen, J. J. P., Van Den Bosch, F. A. J., \& Volberda, H. W. (2005). Managing potential and realized absorptive capacity: How do organizational antecedents matter? The Academy of Management Journal, 48(6), 999-1015.

Ketchen, D. J., Hult, G. T. M., \& Slater, S. F. (2007). Toward greater understanding of market orientation and the resource-based view. Strategic Management Journal, 28(9), 961-964.

Li, T., \& Calantone, R. J. (1998). The impact of market knowledge competence on new product advantage: Conceptualization and empirical examination. Journal of Marketing, 62(4), 13-29.

Lin, H.-F. (2007). Knowledge sharing and firm innovation capability: An empirical study. International Journal of Manpower, 28(3/4), 315-332.

Luo, X., \& Hassan, M. (2009). The role of top management networks for market knowledge creation and sharing in China. Journal of Business Research, 62(10), 1020-1026.

Luo, X., Slotegraaf, R. J., \& Pan, X. (2006). Cross-functional "coopetition”: The simultaneous role of cooperation and competition within firms. Journal of Marketing, 70(2), 67-80. 
Maltz, E., \& Kohli, A. K. (1996). Market intelligence dissemination across functional boundaries. Journal of Marketing Research, 33(1), 47-61.

Maltz, E., Souder, W. E., \& Kumar, A. (2001). Influencing R\&D/marketing integration and the use of market information by R\&D managers: Intended and unintended effects of managerial actions. Journal of Business Research, 52(1), 69-82.

Martinez, J. I., \& Jarillo, J. C. (1989). The evolution of research on coordination mechanisms in multinational corporations. Journal of International Business Studies, 20(3), 489-514.

Nahapiet, J., \& Ghoshal, S. (1998). Social capital, intellectual capital, and the organizational advantage. Academy of Management Review, 23(2), 242-266.

Narver, J. C., \& Slater, S. F. (1990). The effect of a market orientation on business profitability. Journal of Marketing, 54(4), 20-35.

Nguyen, P. N. (2014). The impact of coordination and competition on cross-functional knowledge sharing and organizational performance. DBA Thesis. New South Wales, Australia: Western Sydney University.

Olavarrieta, S., \& Friedmann, R. (2008). Market orientation, knowledge-related resources, and firm performance. Journal of Business Research, 61(6), 623-630.

Padula, G., \& Dagnino, G. B. (2007). Untangling the rise of coopetition. International Studies of Management and Organization, 37(2), 32-52.

Persson, M. (2006). The impact of operational structure, lateral integrative mechanisms, and control mechanisms on intra-MNE knowledge transfer. International Business Review, 15(5), 547-569.

Podsakoff, P. M., MacKenzie, S. B., Lee, J.-Y., \& Podsakoff, N. P. (2003). Common method biases in behavioral research: A critical review of the literature and recommended remedies. Journal of Applied Psychology, 88(5), 879-903.

Quintana-Garcia, C., \& Benavides-Velasco, C. A. (2004). Cooperation, competition, and innovative capability: A panel data of European dedicated biotechnology firms. Technovation, 24(12), 927938.

Ratnatunga, J., Pike, R., \& Hooley, G. J. (1988). The application of management accounting techniques to marketing. Accounting and Business Research, 18(72), 363-370.

Reagans, R., \& McEvily, B. (2003). Network structure and knowledge transfer: The effects of cohesion and range. Administrative Science Quarterly, 48(2), 240-267.

Rindfleisch, A., \& Moorman, C. (2001). The acquisition and utilization of information in new product alliances: A strength-of-ties perspective. Journal of Marketing, 65(2), 1-18.

Sandvik, I. L., \& Sandvik, K. (2003). The impact of market orientation on product innovativeness and business performance. International Journal of Research in Marketing, 20(4), 355-376.

Sidhu, B. K., \& Roberts, J. H. (2008). The marketing accounting interface-Lessons and limitations. Journal of Marketing Management, 24(7-8), 669-686. 
Tagliaventi, M. R., Bertolotti, F., \& Macrì, D. M. (2010). A perspective on practice in interunit knowledge sharing. European Management Journal, 28(5), 331-345.

Tsai, W. (2001). Knowledge transfer in intraorganizational networks: Effects of network position and absorptive capacity on business unit innovation and performance. Academy of Management Journal, 44(5), 996-1004.

Tsai, W. (2002). Social structure of "coopetition" within a multiunit organization: Coordination, competition, and intraorganizational knowledge sharing. Organization Science, 13(2), 179-190.

Uzzi, B. (1997). Social structure and competition in interfirm networks: The paradox of embeddedness. Administrative Science Quarterly, 42(1), 35-67.

Walley, K. (2007). Coopetition. International Studies of Management and Organization, 37(2), 1131.

Willem, A., \& Buelens, M. (2007). Knowledge sharing in public sector organizations: The effect of organizational characteristics on interdepartmental knowledge sharing. Journal of Public Administration Research and Theory, 17(4), 581-606.

Willem, A., \& Buelens, M. (2009). Knowledge sharing in inter-unit cooperative episodes: The impact of organizational structure dimensions. International Journal of Information Management, 29(2), 151-160.

Willem, A., Buelens, M., \& Scarbrough, H. (2006). The role of inter-unit coordination mechanisms in knowledge sharing: A case study of a British MNC. Journal of Information Science, 32(6), 539-561.

Zhang, Y., \& Begley, T. M. (2011). Power distance and its moderating impact on empowerment and team participation. The International Journal of Human Resource Management, 22(17), 36013617. 